\title{
Evolution of lead concentrations in the Nervión Estuary, southeastern Bay of Biscay
}

\author{
JOANA LARRETA, JAVIER FRANCO and VICTORIANO VALENCIA \\ AZTI-Tecnalia, Marine Research Division, Herrera Kaia, Portualdea z/g, 20110 Pasaia, Gipuzkoa, Spain.
} E-mail: jlarreta@azti.es

\begin{abstract}
SUMMARY: Over many years the Nervión estuary has received an intense lead input from various sources in relation to different human activities. This input has produced lead accumulation in some compartments of the estuarine system, which is mainly reflected in the sediments. In recent years, the closure and/or transformation of some contaminating industries, in addition to the implementation of a sewerage scheme, have considerably reduced these inputs into the system. The lead concentration in the sediments has shown a general decreasing trend since 1995. Although this trend is neither progressive nor statistically significant for all the studied stations, lead concentrations in surficial sediment are significantly lower in recent years than at the beginning of the study period. Regarding potential adverse effects on biota, although one third of the values measured during the study period are above concentrations associated with toxicity, in recent years very few values exceed these references. Time series of lead concentrations in biomonitors (mussels) do not show statistically significant temporal trends, and most of the values fulfil the quality objective proposed for this region.
\end{abstract}

Keywords: lead, pollutants, sediments, water, biomonitors, Nervión estuary.

RESUMEN: EVOlución DE LAS CONCENTRACIONES DE PLOMO EN EL ESTUARIO DEL NERVIÓN, SUDESTE DEL GOLFO DE VIZCAYA. - El estuario del Nervión recibió durante muchos años elevados aportes de plomo procedentes de diferentes actividades humanas desarrolladas en los márgenes del estuario. Esto produjo la acumulación de plomo en diferentes compartimentos del sistema, siendo el sedimento el compartimiento donde más claramente se refleja. En los últimos años, el cierre y/o transformación de algunas de las industrias más contaminantes, además de la implementación de un plan de saneamiento, han reducido considerablemente las entradas de plomo en el sistema. Las concentraciones de plomo en los sedimentos presentan una tendencia general decreciente desde el año 1995. Aunque esta tendencia no es progresiva ni estadísticamente significativa en todas las estaciones estudiadas, la concentración de plomo en el sedimento superficial es menor en los últimos años que al comienzo del periodo de estudio. En lo que respecta a los efectos adversos en la biota, aunque un tercio de los valores medidos durante el periodo de estudio están por encima de las concentraciones asociadas a toxicidad, en los últimos años solo unos pocos valores exceden dichas referencias. Las series temporales de plomo en biomonitores (mejillones) no presentan una tendencia temporal estadísticamente significativa y la mayoría de los valores cumplen con los objetivos de calidad propuestos para esta región.

Palabras clave: plomo, contaminantes, sedimentos, agua, biomonitores, estuario del Nervión.

\section{INTRODUCTION}

Lead and its compounds are some of the priority substances present in all the directives amending the WFD Directive 2000/60/EC, such as Directive 2008/105/CE of the European Parliament and Council.

Lead is abundant and widespread but is not a major element of the Earth's crust. This metal is an extremely reactive element, removed rapidly from the water column through its association with particulates and subsequent sedimentation. Lead is used widely in human activities. Consequently, lead has been extracted from minerals, concentrated and re-distributed under different chemical forms in almost all environments and ecosystems. Therefore, lead has become a characteristic representative of contamination (undesirable excess of concentration) and pollution (adverse effects and environmental concerns). It is classed as 
a 'scavenged element', and dissolved concentration profiles in the marine environment show a continuous decrease between the surface and the bottom of the estuaries. Due to environmental and health problems, lead has been studied widely for many years. Hence, the biogeochemistry of lead (natural and anthropogenic sources and pathways) is well known and is one of the typical elements studied/measured in environmental monitoring programs, within coastal and estuarine environments. This is also the case for the Nervión estuary (Borja et al. 2008a, Franco et al. 2008), a system located in the southeastern corner of the Bay of Biscay.

Taking into account the geochemical composition of the underlying geological strata of the Nervión estuary region, which is dominated by a blenda-galenapyrite-chalcopyrite paragenesis, the sediments are naturally enriched in some elements, particularly $\mathrm{Fe}$, $\mathrm{Zn}$ and $\mathrm{Pb}$ (Pascual et al. 2004, Rodriguez et al. 2006, Belzunce et al. 2004a, 2004b).

During many decades the Nervión estuary has received untreated domestic and industrial wastes from numerous and diverse sources, including mining and steel factories. Mineral slags and highly polluted dredged sediments were dumped in the adjacent coast$\mathrm{al}$ area. These inputs were discharged and accumulated in different environmental compartments, such as air, water, sediments and biota.

These inputs have led to a very marked deterioration of the estuary, which shows oxygen depletion, a high concentration of contaminants within the water and the sediments, loss of animal life, and bacteriological pollution, among others (Saiz-Salinas and González-Oreja 2000, Belzunce et al. 2004b). Due to the high loads of toxic pollutants, such as trace metals, some sediments could be deemed to be toxic for animal life, as they are a potential source of diffuse pollution (González-Oreja and Saiz-Salinas 2003).

In order to reverse the situation of poor environmental quality, a sewerage scheme for the area was approved in 1979. The aim of this scheme was the overall recovery of the system. A water quality standard, based on dissolved oxygen in the water, was established. Water cleansing started in 1990, with a physico-chemical primary treatment; in 2001, a biological treatment plant came into operation. Furthermore, for many years the main source of lead inputs to the atmosphere has been the emissions from vehicles using leaded gasoline (Bryan 1985); however, this fuel went out of use in the late 20th Century. In addition, many industries associated with lead inputs closed down, they were restructured or they improved their waste management processes, resulting in a reduction in the lead within the system.

In order to make a comprehensive survey of the estuarine quality over time, a monitoring programme (including the biotic and the abiotic components) has been carried out since 1989. The results from this monitoring programme show a clear improvement in both the abiotic and biotic components (García-Barcina et al. 2006, Borja et al. 2006, 2008b, Uriarte and Borja
2009). In addition to the progressive implementation of the sewerage scheme, some of this improvement should be attributed to the transformation of the surrounding areas of the estuary and the whole river basin, and especially to the decline/transformation of some of the most polluting industries, i.e., mining, steel factories and shipyards.

The main objective of the present study is to explain the temporal trends in the lead concentrations in different compartments of the estuary, and relate these to the main sources and the measures taken to improve the quality of the system.

\section{MATERIALS AND METHODS}

\section{The study area}

The Nervión estuary is located in the Cantabrian Sea, in the southeastern corner of the Bay of Biscay; it is located within the province of Bizkaia, Basque Country (N. Spain) (Fig. 1). The Nervión estuary and its surroundings is the most populated urban area in the north of Spain. The total population in the area is 1 million inhabitants.

The Nervión estuary is the largest estuarine system of the Basque Country, and has a length of $22 \mathrm{~km}$ from its outer limit, located between Punta Lucero and Punta Galea, to the inner tidal limit, situated within the city of Bilbao. It is also the largest $\left(29.2 \mathrm{~km}^{2}\right)$ and the deepest (including depths of $30 \mathrm{~m}$ in its outermost area). Tidal amplitudes vary between around $1 \mathrm{~m}$ in neap tides, to more than $4.5 \mathrm{~m}$ in spring tides; as such, it can generally be considered as a mesotidal system (Valencia et al. 2004a).

Overall, the tributaries of the estuary drain a surface area of around $1,800 \mathrm{~km}^{2}$ and the river flow has a mean value of around $36 \mathrm{~m}^{3} \mathrm{~s}^{-1}$ (García de Bikuña and Docampo 1990). These values represent, with in the context of the Basque Country, $34 \%$ of the surface of the Atlantic river basins and $24 \%$ of the river runoff through the estuaries to the Cantabrian Sea (Eraso et al. 2001, Valencia et al. 2004b, Borja et al. 2006).

In terms of the morphology and hydrography, two main parts can be distinguished (Fig. 1): an inner artificial channel, which is heavily stratified in the water column, with maximum depths of around $10 \mathrm{~m}$ and average surface salinities of between 0 and 25 psu, which was created originally for navigation purposes; and a slightly stratified outer area with water depths ranging between 10 and $30 \mathrm{~m}$ and average surface salinities $>25 \mathrm{psu}$, where most of the port facilities are located. Both areas, especially the inner one, have been dredged intensively. A permanent salt wedge is found within the bottom layer of the water column, with salinities are generally $>30$ psu. Salinity differences between the surface and bottom waters increase upstream. Therefore, in the innermost reach of the Nervión estuary, oligohaline water is usually found at the surface, whilst polyhaline water is normally 


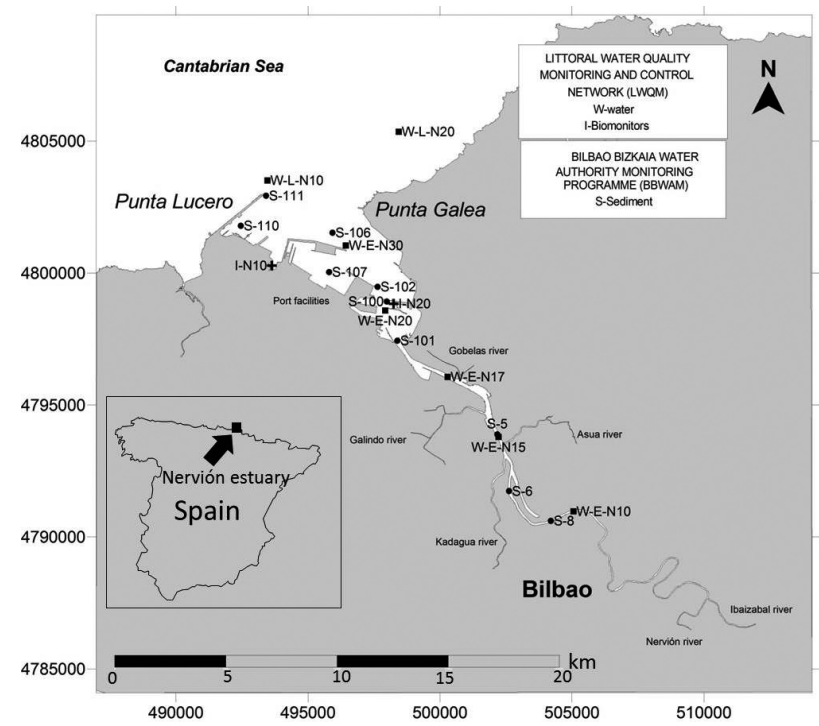

FIG. 1. - Map of the Nervión estuary, showing the general location, river systems and sampling stations. Key: $\mathbf{\square}$, water; +, biomonitors; and $\bullet$, sediments.

present within the bottom layer.

The mean volume of the Nervión estuary is $40010^{6}$ $\mathrm{m}^{3}$. This is much greater than the rest of the estuaries in the Basque Country. Most of this volume (>90\%) corresponds to the outer part of the estuary. Taking into account the high volume, the mean river flow and the tidal influence, the water residence time has been calculated to be in the order of several weeks (Valencia et al. 2004b).

\section{Sampling and survey programmes}

\section{Water samples}

Within the study area, the main source of data on dissolved $\mathrm{Pb}$ originates from the Littoral Water Quality Monitoring and Control Network (hereafter, LWQM), in operation since 1994 as part of the Basque Water Agency (Department of Environment, Land Planning, Agriculture and Fishing of the Basque Government). Five sampling stations are located in the Nervión estuary and two additional stations in the adjacent coastal area (Fig. 1). Surveys are performed twice a year and samples are collected in the surface waters.

Water samples from the tributaries (Ibaizabal, Nervión, Asua, Kadagua, Galindo and Gobelas) of the estuary have been collected since 1994 . The results obtained for these samples were provided by the Basque Water Agency (Agencia Vasca del Agua, URA).

\section{Sediment samples}

Ten sampling locations, distributed along the estuary, were studied. This information was provided by the "Bilbao Bizkaia Water Authority Monitoring Programme" (hereafter, BBWAM) in operation since 1989 (Fig. 1). The sampling was carried out annually, in
September-October. Sediment samples were collected using a Day grab. The upper $10 \mathrm{~cm}$ of sediments was recovered. Sediment samples were retained in plastic bottles and stored at $4^{\circ} \mathrm{C}$ until analysis (see Rodriguez et al. 2006).

\section{Biomonitors (mussel samples)}

Two sampling stations of biomonitors (Mytilus galloprovincialis), located in the outer part of the estuary, were sampled twice a year (Fig. 1). This information comes from the LWQM, in operation since 1994.

\section{Sample treatment and analytical methods}

\section{Water samples}

Water samples were filtered using standard MF Millipore membrane filters $(0.45 \mu \mathrm{m}$ pore size $)$. Lead contents were determined by flame atomic absorption spectrometry (AAS), or electrothermal atomic absorption spectrometry (ETAAS), with Zeeman background correction. Seawater samples were separated from interfering matrix components (Pai 1988, Pohl and Prusisz 2004, Pohl 2006), preconcentrated with CHELEX 100 ion-exchange resin. The $\mathrm{pH}$ value of each sample was set to 5.4 with ammonium acetate. In general, quality assurance testing relies on the control of blanks and on the accuracy and reproducibility of data, relative to standard reference materials BCR 505, i.e. estuarine water delivered by the IRMM (Belgium). The results obtained here were in good agreement with the certified values (for details, see Tueros et al. 2008).

\section{Sediment samples}

Lead concentrations in sediment were analysed within the silt and clay fraction (i.e. $<63 \mu \mathrm{m}$ ) (Loring and Rantala 1992, Rodriguez et al. 2006). For the sediment samples, the $63 \mu \mathrm{m}$ fraction was obtained by dry sieving the samples, which had been previously oven-dried at $60^{\circ} \mathrm{C}$. Samples were digested in an acid mixture $\left(\mathrm{HCl}\right.$ and $\left.\mathrm{HNO}_{3}, 2: 1 \mathrm{v} / \mathrm{v}\right)$ in a high pressure microwave digestion system. The lead determination in the extracts was carried out using atomic absorption spectroscopy. The accuracy of the analytical procedures used for the analysis of the metals in the sediment samples was checked using the PACs-2 (NRC, National Research Council Canada) port sediment certified reference material, with a recovery of $90 \%$ for lead.

\section{Mussel samples}

Before the samples were prepared, the mussels were depurated for $24 \mathrm{~h}$ in clean seawater. Then, the soft tissues were homogenized and freeze-dried using a lyophilizer system. Digestion was performed in a microwave digestion system, using concentrated $\mathrm{HNO}_{3}$. 

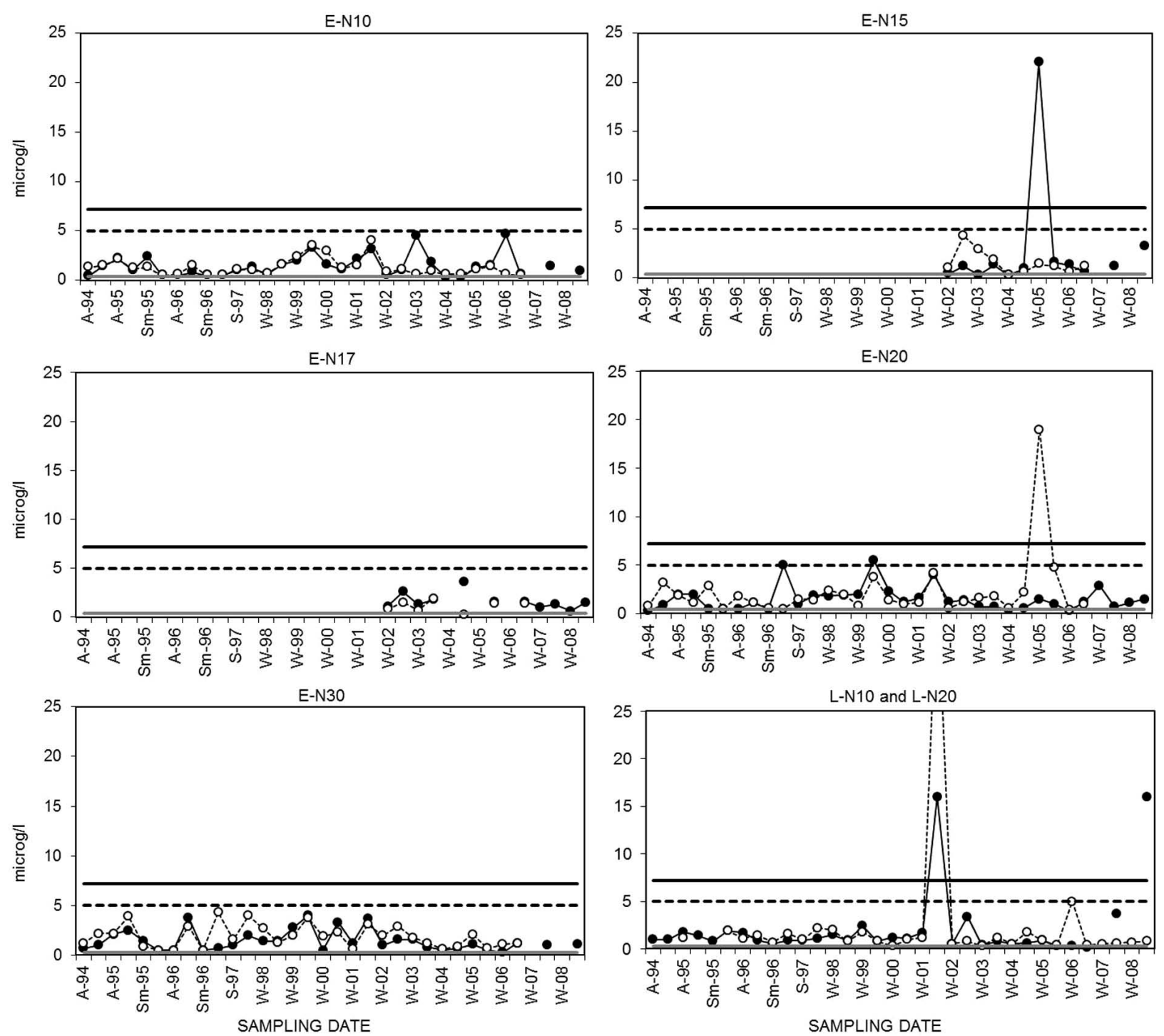

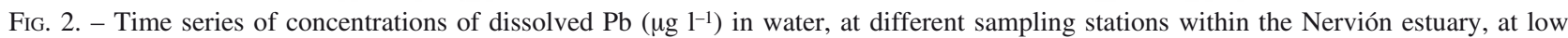
and high tide, and in the adjacent coastal area. Data from LWQM: A-Autumn; W-Winter; S-Spring; Sm-Summer. The grey line indicates a background value $\left(0.4 \mu \mathrm{g}^{-1}\right)$, the black line the target value proposed by the WFD $\left(7.2 \mu \mathrm{g}^{-1}\right)$ and the dotted line the OSPAR toxicity $(5 \mu \mathrm{g}$ $1^{-1}$. Key: $\bullet$, low tide; $O$, high tide.

The amount of lead in the extracts was determined using atomic absorption spectroscopy with a graphite furnace. The accuracy of the method used was confirmed with BCR 278R (Mussel Tissue) standard reference material from the European Reference Materials (Franco et al. 2002), with a recovery of $95 \%$ of the lead.

\section{Statistical analyses for studying temporal trends}

The Mann-Kendall test was applied in order to detect increasing or decreasing trends in the time series for the water, sediment and biomonitor samples. This method is non-parametric and is able to detect increasing or decreasing trends in time series with a given confidence level. The analyses of temporal trends in the sediments, with one data point for each year, was carried out with the Excel template MAKESENS
(Mann-Kendall test for trend and Sen's slope estimates on annual data, Version 1.0 2002). The analyses of temporal trends in the water and biomonitor samples were carried out with the Kendall.exe program (from the Kendall family of trend tests), which takes into account the seasonality of the data over the years (Helsel et al. 2006).

\section{RESULTS}

\section{Water}

The temporal trend of the lead concentration in water at the six sampling stations is shown in Figure 2; however, no clear temporal trends were observed. The annual mean concentrations at the three innermost sampling stations of the estuary, together with the corresponding 

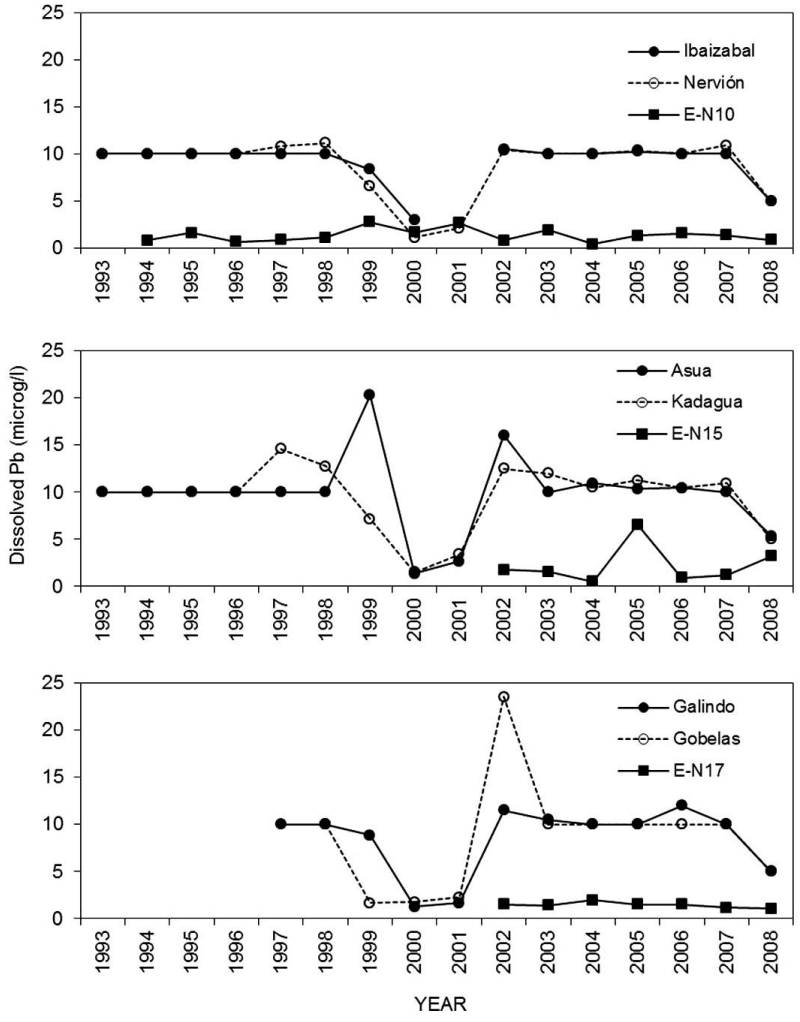

FIG. 3. - Time series of dissolved $\mathrm{Pb}$ concentrations in water in the main tributaries (Asua, Kadagua, Ibaizabal, Nervión, Galindo and Gobelas) and in the nearest estuarine sampling stations (for locations see Fig. 1). Data correspond to mean annual values. Note: data for the tributaries were provided by the Basque Water Agency.

tributaries, are represented in Figure 3. However, this latter series does not show adequate data discrimination because most of the values obtained correspond to the detection limit and also reflect differences in the analytical methods. Nevertheless, considering the data points that are significantly different from the detection limit, the concentrations in the tributaries are similar, or higher, than the concentrations recorded for the estuary. Although the overall concentration range is relatively high (mainly because of the specific maximum in 2001 and 2002 at the littoral stations (L-N10 and L-N20) and in 2005 at the estuarine stations (E-N15 and E-N20)), the values are generally below the quality objective established by the WFD $\left(7.2 \mu \mathrm{g}^{-1}\right)$ : more than $75 \%$ of the cases are below the reference values established by OSPAR $\left(5 \mu \mathrm{g} \mathrm{l}^{-1}\right)$.

No dilution pattern associated with the salinity gradient was observed in the estuary, but a high spatial and temporal variability was detected. This was also the case for the littoral sampling stations (L-N10 and L-N20). Most of the lowest values were observed in the 1994-2001 period.

\section{Sediment}

Lead concentrations in the sediments were well above regional background levels (estimated at $31 \mathrm{mg}$
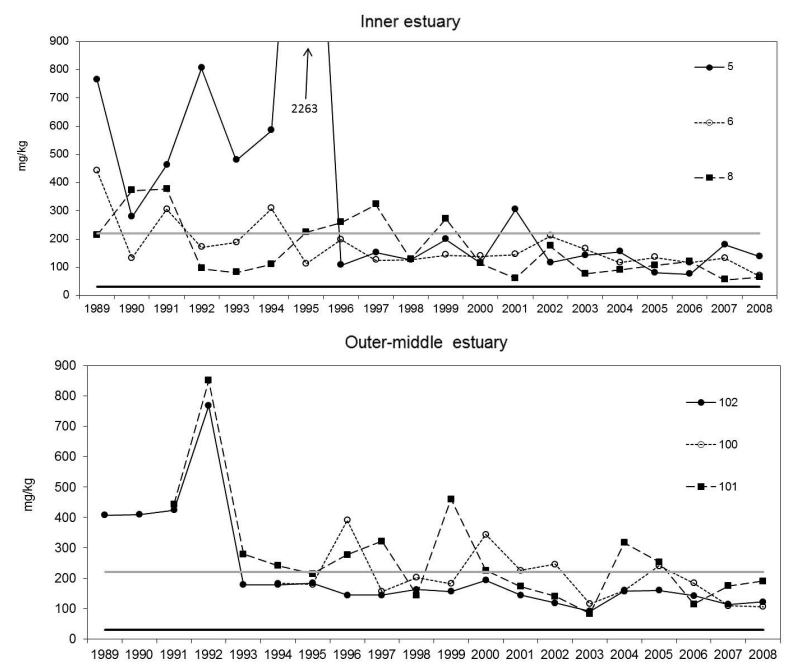

Outer estuary

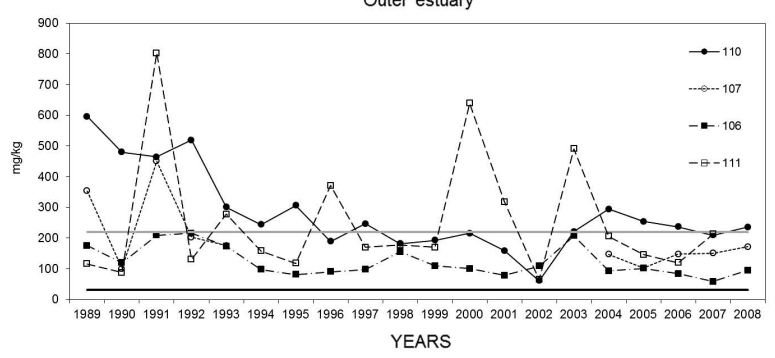

FIG. 4. - Time series of $\mathrm{Pb}$ concentration $\left(\mathrm{mg} \mathrm{kg}^{-1}\right)$ in the sediments ( $<63 \mu \mathrm{m}$ fraction) of the Nervión estuary (for station locations see Fig. 1). The grey line corresponds to the Effects Range Median (218 $\mathrm{mg} \mathrm{kg}^{-1}$; Long et al. 1995) and the black line to the background value (31 mg kg-1; Rodríguez et al. 2006). Note: data from BBWAM.

$\mathrm{kg}^{-1}$ by Rodríguez et al. 2006) in all areas of the system (Fig. 4). Up until 1996, high concentrations were measured at several stations corresponding to the different areas of the system, especially at Station 5 (inner estuary). Since 1996, the highest values have been measured in the outer and middle parts of the estuary. Regarding temporal trends, statistically significant decreasing temporal trends were found for all the studied sampling stations with $\mathrm{p}<0.05$, and for sampling stations 102 and 5 with $\mathrm{p}<0.001$ and $\mathrm{p}<0.01$ respectively. At most of the stations, lead concentrations in the surficial sediments are clearly lower in recent years than at the beginning of the sampling period (Fig. 4). Overall, lead concentrations in the sediments show an initial decreasing trend then a stabilization pattern in latter years.

Regarding potential adverse effects on the biota, all of the measured lead concentrations in the surficial sediments are above the Effects Range Low (ERL, 47 $\mathrm{mg} \mathrm{kg} \mathrm{k}^{-1}$ ) and around one third of them are above the Effects Range Median (ERM, $218 \mathrm{mg} \mathrm{kg}^{-1}$ ) (Long et al. 1995). This pattern suggests that lead could have been affecting benthic organisms adversely. However, it must be taken into account that ERL and ERM values refer to concentrations in all of the sediment fractions, whereas lead concentrations in the Nervión estuary are 


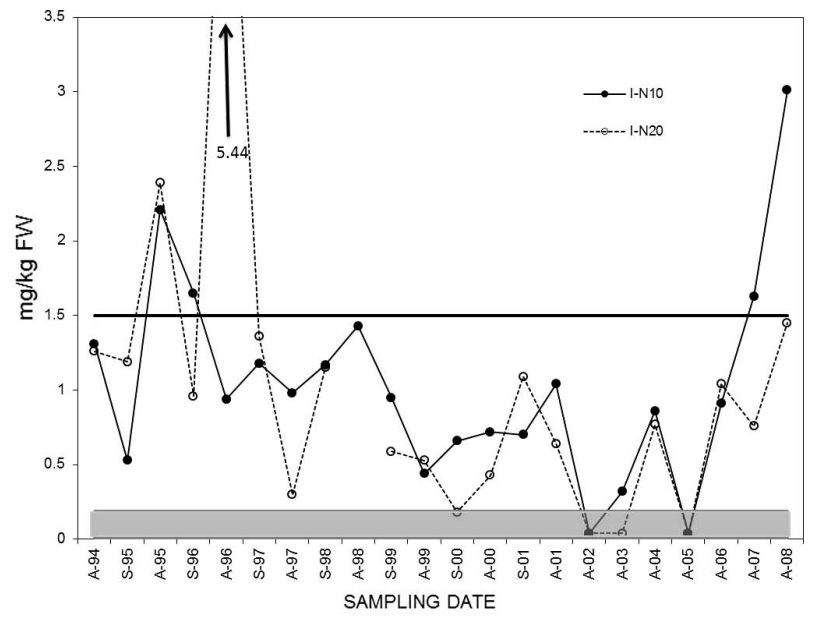

FIG. 5. - Lead concentrations in mussels at two sampling stations located in the outer part of the Nervión estuary (see Fig. 1). The black line indicates the quality target value $\left(1.5 \mathrm{mg} \mathrm{kg}^{-1}\right)$ and the grey area the OSPAR range of values $\left(0.01-0.19 \mathrm{mg} \mathrm{kg}^{-1}\right)$. Note: data from LWQM.

only measured in the fine-grained fraction. This implies that the potential adverse effects are overestimated when ERL and ERM references are applied. Stations 110 and 101 show the highest proportion of lead values above ERM. Most of the values exceeding the ERM correspond to the first years of the sampling period, and in recent years, very few values above ERM have been measured (Fig. 4).

\section{Biomonitors}

Lead concentrations in biomonitors (mussels) were sampled by the LWQM twice a year from 1994 to 2001, and then after that, once a year in autumn; no statistically significant temporal trends have been detected (Fig. 5). The quality objective proposed for this region (1.5 $\mathrm{mg} \mathrm{kg}^{-1} \mathrm{FW}$; Borja et al. 1996) by the Commission regulation CE/1881/2006 was fulfilled in all of the campaigns, except in 1995 at two sampling sites (I-N10 and I-N20), in 1996 at I-N20, and in the last two years of the study (2007 and 2008) at I-N10. Most of the values obtained were between the upper background value proposed by OSPAR $\left(0.19 \mathrm{mg} \mathrm{kg}^{-1}\right)$ and the quality objective value. In the case of I-N10 in autumn 2002 and autumn 2005 and I-N20 in autumn 2003 , the values lay between $0.010 \mathrm{mg} \mathrm{kg}^{-1}$ and the upper background value proposed by OSPAR. The concentrations measured in this study lie within the range of the values observed in other studies of the Basque coastal area (Solaun et al. 2001, Franco et al. 2002).

\section{DISCUSSION}

\section{Water}

The absence of any direct relationships between the estuarine/river inputs and the concentrations in the estuary, the absence of temporal trends in the water and the irregular distribution of concentrations with respect to salinity, indicates multiple sources and complex processes for lead distribution in the estuary.

Taking into account the morphology and the human uses of the estuary, direct inputs from the industrial zones and port activities, direct run-off and mobility and exchange with the sediment could be expected. Furthermore, these processes could be affected by harbour activities, such as dredging, sediment disposal, etc.

The high variability in the lead concentrations observed in this study is related to the behaviour of lead in transitional estuarine waters. In general, metals have a very complex behaviour in this kind of estuarine waters in relation to factors that affect biogeochemistry processes, which show high variability during the mixing estuarine processes (Michel et al. 2000). For some of the metals and for specific estuaries or costal river plumes, the distribution of trace metals is related to salinity (Elbaz-Poulichet et al. 1996, Owens and Balls 1997a, Nolting et al. 1999), reflecting the importance of mixing processes.

However, in the Nervión estuary, as observed in other estuarine systems, dissolved lead concentrations appear to be regulated more by diverse and diffuse inputs (direct run-off, secondary effluent and sediment lead mobilization) than by salinity distribution within the estuary (Monbet 2006, Tueros et al. 2008). Therefore, conservative behaviour of dissolved lead is not normally observed within the estuary (Tueros et al. 2009). The observed variability could be explained by estuarine sedimentation and subsequent re-suspension processes, which would affect the total metal concentrations in relation to the suspended particulate matter (SPM). For the dissolved phase, precipitation and coprecipitation decrease the metal concentration (Morris 1986). Conversely, desorption from SPM, formation and stabilization of complexes with organic or inorganic ligands, re-dissolution from sediments and diffusion from pore water, can all increase the dissolved metal content within the water column. These processes also vary along the estuarine mixing and might change the metal balance between the dissolved and particulate phases for different salinity intervals (Owens et al. 1997b, Gerringa et al. 2001, Monbet 2006, Audry et al. 2007).

\section{Sediment}

Sediment is an essential, integral and dynamic part of the water cycle. This is especially true in estuaries, where physico-chemical as well as biogeochemical processes cause complex interactions between sediments and the water column. In the Nervión estuary sediments have degraded rapidly since the industrialization period, and the quality of the sediments has decreased drastically (Cearreta et al. 2002, Belzunce et al. 2004a). Sediments are still an important reservoir of lead in the study area, which is reflected in the values obtained along the estuary, which are clearly higher 
than the background regional values (Rodriguez et al. 2006). However, few values above ERM have been measured in recent years. This pattern is related to the decrease in lead contamination in the surficial sediments and a consequent improvement in the estuarine bed, facilitating benthic recovery, as has been observed in several other studies (e.g. Borja et al. 2006).

Different studies, based on the sequential extraction of metals in the sediments of this estuary, have shown that a high proportion of lead is associated with the three most mobile forms, which can be transformed easily, liberating cations into the water column (Belzunce et al. 2004b). However, the residual phase is present in significant proportions and is dominant at some stations (i.e. 102, 100 and 101), which demonstrates its origin associated with iron and steel manufacturing and the mineralogy of the basin (Belzunce et al. 2004b, Borja et al. 2008b).

Different studies of percussion cores from several sites of the Nervión estuary (Cearreta et al. 2002, Belzunce et al. 2004b, Arias et al., 2008) have distinguished three historical environmental zones related to the industrial activity (Cearreta et al. 2002). Thus, in the middle estuary, due to intense dredging operations carried out for navigational purposes, higher lead concentrations were detected in the upper parts of the cores (0-1 m) than in the lower parts (Cearreta et al. 2002, Belzunce et al. 2004b, Arias et al. 2008). However, in the outer and middle reaches, higher lead concentrations were measured both in the upper and lower parts of the cores. These observations all indicate that the vertical distribution of $\mathrm{Pb}$ in the sediments is somewhat irregular and depends mostly on the human activities in the different areas of the system.

Overall, the observed general decrease in $\mathrm{Pb}$ in the surficial sediments of the estuary reflects the reduction in $\mathrm{Pb}$ inputs into the system.

\section{Biomonitors}

Mussels, as marine organisms, have the ability to accumulate metallic contaminants from the environment in which they live. As such, they have been used widely in monitoring programmes to assess the quality of the marine environment because they integrate information over higher resolution time-periods than sediments (Goldberg 1975). The absence of any temporal trend in $\mathrm{Pb}$ in the biomonitors is in agreement with the high variability recorded in the waters.

\section{CONCLUSIONS}

For many years the Nervión estuary has received an intense input of lead from various sources in relation to different human activities (mining, steel industries, atmospheric emissions from vehicles, etc.). This input has resulted in lead accumulation in some compartments of the estuarine system, reflected mainly in the sediments. In recent years, the closure and/or transfor- mation of some contaminating industries, in addition to the implementation of a sewerage scheme, have reduced the lead inputs considerably. However, due to the high variability of estuarine systems and to the effects of diverse human activities, this reduction in $\mathrm{Pb}$ inputs was not reflected in any temporal trend in the water and biomonitor compartments. In contrast, the lead concentration in the sediments shows a general decreasing trend. Although this trend is neither progressive nor statistically significant for all the stations studied, the lead concentrations in surficial sediment are now significantly lower than at the beginning of the study period (around 20 years ago). Regarding potential adverse effects on biota, although one third of the values measured during the studied period lie above concentrations associated with toxicity, in recent years very few values exceed these reference levels.

Furthermore, all of the above results are in accordance with those obtained from monitoring of biological communities, especially benthic invertebrates, and reflect the overall improvement in the environmental quality of the system.

\section{ACKNOWLEDGEMENTS}

J. Larreta was supported by the programme Torres Quevedo (Ministerio de Educación y Ciencia and Fondo Social Europeo). Data used in this contribution were obtained from various studies, supported by different conventions between AZTI-Tecnalia and several organizations and institutions, such as the Basque Water Agency and the Bilbao Bizkaia Water Authority. We also wish to thank Professor Michael Collins (School of Ocean And Earth Science, University of Southampton, UK) for kindly advising us on some details of this paper.

\section{REFERENCES}

Arias R., Barona A., Ibarra-Berastegi G., Aranguiz I., Elais A. 2008. Assessment of metal contamination in dregded sediments using fractionation and Self-Organizing Maps. J. Hazard. Matter. 151: 78-85.

Audry S., Blanc G., Schafer J., Guerin F., Masson M., Robert S. 2007. Budgets of $\mathrm{Mn}, \mathrm{Cd}$ and $\mathrm{Cu}$ in the macrotidal Gironde estuary (SW France). Mar. Chem. 107: 433-448.

Belzunce M.J., Solaun O., Valencia V., Pérez V. 2004a. Contaminants in estuarine and coastal waters. In: Borja A, Collins M, editors. Oceanography and marine environment of the Basque Country, Elsevier Oceanography Series vol. 70, pp. 233-251.

Belzunce M.J., Solaun O, González-Oreja J.A., Millán E, Pérez V. 2004b. Contaminants in sediments. In: Borja A., Collins M. (eds), Oceanography and marine environment of the Basque Country. Elsevier Oceanography Series vol. 70, pp. 283-315.

Borja A., Valencia V. 1996. Six années, 1990-1995, de surveillance de la qualité des eaux pour l'aquaculture au Pays Basque (Espagne). In: Taussik J., Mitchell J. (eds), Partnership in Coastal Zone Management. Samara Publishing Ltd, Cardigan, pp. 647-654.

Borja A., Galparsoro I., Solaun O., Muxika I., Tello E.M., Uriarte A., Valencia V. 2006. The European Water Framework Directive and the DPSIR, a methodological approach on assessing the risk of failing to achieve the good ecological status. Est. Coast. Shelf Sci. 66: 84-96.

Borja A., Bald J., Belzunce M.J., Franco J., Garmendia J.M., Larreta 
J., Muxika I., Revilla M., Rodríguez G., Solaun O., Uriarte A., Valencia V., Adarraga I., Aguirrezabalaga F., Cruz I., Laza A., Marquiegui M.A., Martínez J., Orive E., Ruiz J.Mª, Seoane S., Sola J.C., Trigueros J.M., Manzanos A. 2008a. Red de seguimiento del estado ecológico de las aguas de transición y costeras de la Comunidad Autónoma del País Vasco. Masa de agua de la Transición interior y exterior y masa de agua costera Cantabria-Matxitxako. Informe de AZTI-Tecnalia para la Dirección de Aguas del Departamento de Medio Ambiente y Ordenación del Territorio, Gobierno Vasco. Tomo 3, 4 y 16, pp. 40, pp. 38, pp. 32.

Borja A., Tueros I., Belzunce M.J., Galparsoro I., Garmendia J. M., Revilla M., Solaun O., Valencia V. 2008b. Investigative monitoring within the European Water Framework Directive: a coastal blast furnace slag disposal, as an example. J. Environ. Monit. 10: 453-462.

Bryan G.W. 1985. Bioavailability and effects of heavy metals in marine deposits. In: Ketchum B.H., Capuzzo J.M., Burt W.V., Duedall I.W., Park P.K., Kester D.R. (eds) Wastes in the Ocean, Vol 6, Nearshore Waste Disposal. John Wiley and Sons, New York, pp. 42-79.

Cearreta A., Irabien M.J., Leorri, I., Yusta I., Quintanilla A., Zabaleta A. 2002. Environmental transformation of the Bilbao estuary, N. Spain: microfauna and geochemical proxies in the recent sedimentary record. Mar. Pollut. Bull. 44: 487-503.

DIRECTIVE 2008/105/EC OF THE EUROPEAN PARLIAMENT AND OF THE COUNCIL of 16 December 2008 on environmental quality standards in the field of water policy, amending and subsequently repealing Council Directives 82/176/ EEC, 83/513/EEC, 84/156/EEC, 84/491/EEC, 86/280/EEC and amending Directive 2000/60/EC of the European Parliament and of the Council.

DIRECTIVE 2000/60/EC OF THE EUROPEAN PARLIAMENT AND OF THE COUNCIL of 23 October 2000 establishing a framework for Community action in the field of water policy.

Elbaz-Poulichet F, Garnier J.M., Guan D.M., Martin J.M., Thomas A. J. 1996. The conservative behaviour of trace metals $(\mathrm{Cd}, \mathrm{Cu}, \mathrm{Ni}$, and $\mathrm{Pb}$ ) and $\mathrm{As}$ in the surface plume of stratified estuaries: Example of the Rhône River (France). Est. Coast. Shelf Sci. 42: 289-310.

Eraso A., Arrate I., Ruiz F. 2001. Mapa hidrológico de la Comunidad Autónoma del País Vasco, Escala 1:150,000. Departamento de Transportes y Obras Públicas, Gobierno Vasco, 71.

Franco J., Borja A., Solaun O., Perez V. 2002. Heavy metals in molluscs from the Basque Coast (Northern Spain): results from an 11-year monitoring programme. Mar. Pollut. Bull. 44: 956-976.

Franco F., Borja A., Castro R., Larreta J., Muxika I., Revilla M., Uriarte A., Rodríguez G., Villate F., Orive E., Seoane S., Laza A. 2008. Informe: Seguimiento ambiental de los estuarios Del Nervión y Butrón durante 2007. Informe para el Consorcio de Aguas Bilbao Bizkaia, 280 pp. + anexos. Inédito.

García-Barcina J.M., González-Oreja J.A., De la Sota A. 2006. Assessing the improvement of the Bilbao estuary water quality in response to pollution abatement measures. Water Res. 40: 951-960.

García de Bikuña, B., Docampo L. 1990. Limnología de los ríos de Vizcaya. Teorías, aplicaciones e implicaciones biológicas. Dpto. Urbanismo, Vivienda y Medio Ambiente, Gobierno Vasco. Vitoria-Gasteiz.

Gerringa L.J.A., de Baar H.J.W., Nolting R.F., Paucot H. 2001. The influence of salinity on the $\mathrm{Zn}$ and $\mathrm{Cd}$ sulphides in the Scheldt estuary. J. Sea Res. 46: 201-211.

González-Oreja J.A., Sáiz Salinas J.I. 2003. Recovery simulations of grossly polluted sediments in the Bilbao estuary. Mar. Pollut. Bull. 46: 42-48

Goldberg E.D. 1975. The Mussel Watch - a first step in global marine monitoring. Mar. Pollut. Bull. 6: 111.

Helsel D.R., Mueller D.K., Slack J.R. 2006. Computer program for the Kendall family of trend tests: U.S. Geological Survey Scientific Investigations Report 2005-5275, pp. 4.

Long E.D., Macdonald D.D., Smith S.L., Calder F.D. 1995. Incidence of Adverse Biological Effects Within Ranges of Chemical Concentrations in Marine and Estuarine Sediments. Environ. Manage. 19: 81-97.

Loring D.H., Rantala R.T.T. 1992. Manual for the geochemical analysis of marine sediments and suspended particulate matter. Earth Sci. Rev. 32: 235-283.

Michel P., Boutier B., Chiffoleau J.F. 2000. Net fluxes of dissolved arsenic, cadmium, copper, zinc, nitrogen and phosphorus from the Gironde Estuary (France): seasonal variations and trends. Est. Coast Shelf Sci. 51: 451-462

Monbet Ph. 2006. Mass balance of lead through a small macrotidal estuary: the Morlaix River estuary (Brittany, France). Mar. Chem. 98: 59-80.

Morris A.W. 1986. Removal of trace metals in the very low salinity region of the Tamar Estuary. Sci. Total Environ. 9: 297-304

Nolting R.F., Helder W., de Baar H.J.W., Gerringa L.J.A. 1999 Contrasting behaviour of trace metals in the Scheldt estuary in 1978 compared to recent years. J. Sea Res. 42: 275-290.

OSPAR Commission 2000. Quality Status Report 2000: Region IVBay of Biscay and Iberian coast. OSPAR Commission, London, $134+$ XIII pp.

Owens R.E., Balls P.W. 1997a. Dissolved trace metals in the Tay Estuary: implications for monitoring and modelling. Est. Coast Shelf Sci. 44: 421-434

Owens R.E., Balls P.W., Price N.B. 1997b. Physicochemical processes and their effects on the composition of the suspended particulate material in estuaries: implications for monitoring and modelling. Mar. Pollut. Bull. 34: 51-60.

Pai S.C. 1988. Pre-concentration efficiency of chelex-100 resin for heavy metals in seawater. Part 2. Distribution of heavy metals on a chelex-100 column and optimization of the column efficiency by a plate simulation method. Anal. Chim. Acta. 211: 271-280.

Pascual A, Cearreta A, Rodriguez-Lazaro J., Uriarte A. 2004. Geology and palaeoceanography. Oceanography and marine environment of the Basque Country, Elsevier Oceanography Series vol. 70, pp. 53-73.

Pohl P. 2006. Application of ion-exchange resins to the fractionation of metals in water. TrAC Trends Anal. Chem. 25: 31-43.

Pohl P., Prusisz B. 2004. Pre-concentration of $\mathrm{Cd}, \mathrm{Co}, \mathrm{Cu}, \mathrm{Ni}$ and $\mathrm{Zn}$ using different off-line ion exchange procedures followed by the inductively coupled plasma atomic emission spectrometric detection. Anal. Chim. Acta. 502: 83-90.

Rodríguez J.G., Tueros I., Borja A., Belzunce M.J., Franco J., Solaun O., Valencia V., Zuazo A. 2006. Maximum likelihood mixture estimation to determine metal background values in estuarine and coastal sediments within the European Water Framework Directive. Sci. Total Environ. 370: 278-293.

Sáiz-Salinas J.I., González-Oreja J.A. 2000. Stress in estuarine communities: lessons from the highly-impacted Bilbao estuary (Spain). J. Aquat. Ecosys. Stress Recov. 7: 43-55

Solaun O., Borja A., Franco J. 2001. El seguimiento de la calidad de aguas para cultivo de moluscos y marisquea en el País Vasco. Departamento de Agricultura y Pesca. Servicio Central de Publicaciones del Gobierno Vasco. Vitoria-Gasteiz, 94 pp.

Tueros I., Rodriguez J.G., Borja A., Solaun O., Valencia V., Millán E. 2008. Dissolved metal background levels in marine waters, for the assessment of the physico-chemical status, within the European Water Framework Directive. Sci. Tot. Environ. 407: 40-52.

Tueros I., Borja A., Larreta J., Rodríguez J.G., Valencia V., Millán E. 2009. Integrating long-term water and sediment pollution data, in assessing chemical status within the European Water Framework Directive. Mar. Pollut. Bull. 58: 1389-1400.

Uriarte A., Borja A. 2009. Assessing fish quality status in transitional waters, within the European Water Framework Directive: setting boundary classes and responding to anthropogenic Pressures. Est. Coast Shelf Sci. 82: 214-224.

Valencia V., Franco J. 2004a. Main characteristics of the water masses. In: Borja A., Collins M. (eds), Oceanography and Marine Environment of the Basque Country. Elsevier Oceanography Series, vol. 70, pp. 197-232.

Valencia V., Franco J., Borja A., Fontán A. 2004b. Hydrography of the southeastern Bay of Biscay. In: Borja A., Collins M. (eds), Oceanography and Marine Environment of the Basque Country. Elsevier Oceanography Series, vol. 70, pp. 159-194.

Received April 18, 2011. Accepted May 2, 2012.

Published online January 7, 2013. 